\title{
THEORIZING PADA TEORI PENGELOLAAN MODAL KERJA: RELASI ASET LANCAR DAN KEWAJIBAN LANCAR
}

\author{
Shalahuddin Haikal \\ Fakultas Ekonomi dan Bisnis, Universitas Indonesia \\ shalahuddinhaikal@gmail.com
}

\begin{abstract}
Current assets and current liabilities relation is one of the traditional topics of financial management. Through algebra operations, both relations acquired current ratio and net working capital which became a postulate, called the rule of thumbs: current ratio must be greater than 1, and net working capital has to be positive. Based on the findings in two IDX's listed companies, this paper questioning the validity of those rule of thumbs, based on Operation Management, Financial Market evolution and Corporate Governance. This is not an empirical research, this is a theorizing effort which forgotten by scholars in the field of business and management.
\end{abstract}

Keywords: current ratio, working capital, corporate governance

\begin{abstract}
ABSTRAK
Hubungan aset lancar dan liabilitas lancar merupakan topik tradisional dalam manajemen keuangan. Melalui dua operasi aljabar, hubungan keduanya menghasilkan rasio lancar dan modal kerja bersih yang telah menjadi postulat, bahwa rasio lancar harus lebih besar dari satu dan modal kerja bersih harus positip. Hasil temuan pada dua perusahaan blue chip yang tercatat di Bursa Efek Indonesia, menolak kesahihan postulat tersebut dari sudut pandang manajemen operasi, evolusi pasar keuangan dan tentu saja dari sudut pandang Corporate Governance. Manuskrip ini bukan hasil penelitian, melainkan merupakan upaya theorizing yang sudah dilupakan dan diabaikan di bidang manajemen dan bisnis.
\end{abstract}

Kata kunci: rasio lancar, modal kerja bersih, tata kelola perusahaan

\section{PENDAHULUAN}

Rasio lancar (selanjutnya disebut current ratio) adalah salah satu rasio keuangan yang diajarkan dan dipelajari pada sesi kuliah Evaluasi Kinerja Perusahaan pada mata kuliah Manajemen Keuangan. Manajemen Keuangan sendiri merupakan mata kuliah wajib pada kurikulum Fakultas Ekonomi dan Bisnis. Dengan demikian peserta didik yang mengambil mata kuliah ini adalah dari jurusan Ilmu Ekonomi, Akuntansi dan Manajemen. Mata kuliah ini kemudian dilanjutkan dengan mata kuliah yang lebih advance semisal Analisis Laporan Keuangan atau Analisis dan Penggunaan Laporan Keuangan. Current ratio adalah relasi pembagian antara current assets 
dengan current liabilities. Operasi aljabar lainnya dari hubungan current assets dengan current liabilities, yakni pengurangan yang akan menghasilkan modal kerja bersih (selanjutnya disebut net working capital). Istilah net working capital memiliki dua catatan khusus, bahwa penggunaannya interchangeably dengan working capital, juga karena terdapat istilah net, tetapi gross working capital tidak dijelaskan secara eksplisit dan concise.

Penemu istilah yang menghubungkan antara current assets dengan current liabilities dengan dua operasi aljabar tidak dijelaskan sumbernya dalam jurnal-jurnal di bidang finance dan financial management. Bahkan Miller (1999) sama sekali tidak membahasnya, karena justru langsung memulai dari Markowitz and the Theory of Portfolio Selection dan mengakhirinya pada Option. Meskipun diakhiri dengan topik Reconstruction of Finance, tetapi sama sekali tidak menyinggung traditional approach of financial management function (awal abad 20) maupun managerial approach of financial management function (perioda 1920-1960-an). Penelitian ini tidak menemukan pembahasan runtun mengenai evolusi fungsi manajemen keuangan yang dipublikasikan pada jurnal-jurnal keuangan tetapi justru pada International Journal of Education and Research. Saito et al. (2013) secara runtun menjelaskan perkembangan sejak awal abad 20 yang fokus pada struktur modal; periode 1920-1960 yang pengelolaan keuangannya berfokus pada likuditas sampai dengan ketidakrelevanan struktur modal dan dividen; periode 1970-an yang gegap gempita dengan Markowitz portfolio model; CAPM dan efisiensi pasar. Periode 1980-an yang berkhidmat pada Black-Scholes option pricing formula dan periode 1990-awal milenium 2000 yang mulai fokus pada etika, CSR dan behavioral finance. Penelitian ini menyimpulkan bahwa di bidang finance tidak terdapat tradisi theorizing terhadap terms. Di bidang ilmu ekonomi dalam hal ini finance, terjadi kecenderungan untuk meneliti pada context of justification, sehingga peneliti lebih menyukai modelling dan melupakan untuk melakukan olah nalar atas suatu teori (Daniel B Klein \& Romero 2007).

Sebagai suatu pohon ilmu, financial management adalah pohon ilmu yang tumbuh di ranah ilmu sosial karena sifatnya yang mencoba mencari tahu dan menjelaskan bagaimana masyarakat mengelola persoalan-persoalan terkait dengan kelangkaan sumber daya, dalam hal ini sumber daya keuangan. Berbeda dengan ilmu eksakta, perkembangan teknologi atau perubahan lingkungan akan membawa perubahan pada ilmu sosial. Ilmu dimana sesuatu yang semula diyakini sebagai suatu kebenaran akan menjadi bersifat relatif sesuai dengan perkembangan jaman. Sebaliknya pada rumpun ilmu pasti, theorizing bukanlah aktifitas yang tabu atau ditabukan. Menggunakan manuskrip berupa surat menyurat antara Einstein dengan Michele Besso, Janssen (2002) mulai menyoal teori relativitas. Volk (2009) mempertanyakan Mach's Principle, toroidal particles dan catastrophe theory.

Makalah ini merupakan upaya theorizing yang menyoal kesahihan terms current ratio dan (net) working capital terhadap (1) revolusi yang terjadi pada model 
inventory dengan ditemukannya metoda Just in Time dan Zero Inventory dan dikembalikannya model bisnis Factoring dari model kredit bank dengan jaminan piutang; (2) evolusi di bidang financial management yang merupakan pengembangan lebih jauh dari polemik Berle (1931) dengan Dodd (1932) yang empat puluh empat tahun kemudian oleh Jensen dan Meckling (1976) diulas ulang dan diberikan nama Agency Theory dan dua puluh empat tahun setelah memasuki abad ke-21 kemudian meledak karena berbagai skandal korporasi sehingga diberikan nama corporate governance. Upaya-upaya berbagai perusahaan pada berbagai industri yang di kemudian hari diberi nama Supply Chain; Supply Chain Management pada dasarnya adalah upaya untuk memperpendek siklus yang dimulai dari sejak menerima bahan baku atau material, dilanjutkan dengan memproses barang dan memindahkannya ke konsumen (Lummus \& Vokurka 1999). Dalam bahasa Indonesia, seperti halnya teori yang diambil dari theory, saya tidak menemukan padanan yang tepat dalam bahasa Indonesia untuk "theorizing". Theorizing bukanlah kegiatan menyusun teori, tetapi aktifitas mental untuk menelusuri dan napak tilas bagaimana suatu teori dibentuk dan disusun, termasuk di dalamnya menguji kesahihannya dalam context of discovery, dengan mengajukan pertanyaan-pertanyaan dasar, bagaimana seandainya teknologi tertentu telah ditemukan dan bagaimana akibatnya pada teori tersebut. Swedberg (2012) lebih menyukai mendefinisikan theorizing sebagai training in reasoning. Aktivitas menalar pada theorizing termasuk juga menempatkannya pada kondisi lokalitas setempat, misalnya dividend payout ratio yang seolah-olah merupakan keputusan sepihak manajemen, sedangkan di Indonesia yang menganut two-board system of governance, keputusan pembagian dividen adalah keputusan RUPS.

Buku-buku teks standar Manajemen Keuangan menyatakan bahwa bagi kreditur perusahaan, vendor atau supplier misalnya, semakin tinggi current ratio, semakin baik. Sedangkan bagi perusahaan, semakin tinggi current ratio, mengindikasikan likuiditas, tetapi juga merupakan indikasi inefisiensi penggunaan cash dan komponen current assets yang lainnya. Terlepas dari kejadian diluar kebiasaan, diharapkan current ratio sekurang-kurangnya adalah satu, karena jika kurang dari satu maka berarti terjadi kondisi negative net working capital (Roos et al., 2013). Pada current ratio satu, maka net working capital adalah nol. Buku-buku teks standar Analisis Laporan Keuangan menyatakan bahwa rule of thumb perhitungan current ratio yang baik adalah 2:1 atau lebih merupakan indikasi perusahaan yang sehat (financially sound), sedangkan ratio dibawah 2:1 mengindikasikan risiko likuditas yang tinggi (Subramanyam \& Wild 2009). Beberapa buku teks malahan memberikan current ratio rule of thumbs harus lebih dari dua ratus persen.

Durkheim (1982) menyatakan bahwa researcher should proceed from things to idea NOT from idea to thing, maka upaya theorizing ini didasari fakta awal bahwa ternyata dari empat ratus lebih saham yang tercatat di Bursa Efek Indonesia, terdapat dua saham perusahaan multinasional yang merupakan saham darling para investor dan salah satunya selama bertahun-tahun menjadi saham penghuni indeks LQ-45, yang 
justru selama tujuh tahun berturut-turut (termasuk laporan keuangan interimnya), mencatat current ratio lebih kecil dari seratus persen dan karenanya menggunakan term net working capital, memiliki modal kerja bersih negatif. Fakta ini membalik semua keyakinan, tradisi yang diterima dari para dosen yang kemudian diajarkan kepada peserta didik di kelas yang di dapat dari buku-buku teks standar Manajemen Keuangan dan Analisis Laporan Keuangan bahwa perusahaan yang sehat (financially sound) adalah perusahaan yang memiliki current ratio lebih besar dari seratus prosen dan oleh karenanya memiliki net working capital positif.

Oleh karena current ratio perusahaan yang sehat dan kredibel harus bernilai lebih dari seratus persen atau secara rule of thumbs malahan harus lebih dari dua ratus persen, maka berarti nilai current assets lebih besar dari nilai current liabilities. Jika demikian, maka berarti pula terdapat bagian dari current assets yang dibiayai dengan long-term liabilities. Bagi pemegang saham, kondisi tersebut jelas merugikan. Kecuali current portion of long-term debt, seluruh komponen penyusun current liabilities adalah non-interest bearing. Sedangkan long-term debt, baik berasal dari bank loan maupun penerbitan obligasi adalah interest bearing liabilties. Bahkan jika dibiayai dengan penerbitan obligasi konversi yang berbunga rendah, pemegang saham akan terpapar dengan risiko dilusi yang datang manakala bondholder mengkonversi obligasinya dengan saham.

Sebaliknya pada current assets, kecuali akun kas, selebihnya adalah noninterest dan non-earning assets. Dengan saldo kas yang berlebihan sekalipun dan ditempatkan sementara dalam bentuk deposito, sudah pasti tingkat suku bunganya jauh lebih rendah dari suku bunga utang bank jangka pendek ataupun current portion of long-term debt. Sekedar mengingatkan, bahwa akun kas pada current assets adalah hasil penjumlahan saldo kas periode sebelumnya ditambah kenaikan atau penurunan bersih pada kas dan setara kas pada Laporan Arus Kas, yang kesemuanya sudah diamini untuk disebut sebagai free cash flows. Sedangkan kita semua juga sudah setuju bahwa free cash flows merupakan obyek misapropriasi hak-hak pemegang saham oleh manajemen.

Pemegang saham menjadi fokus karena salah satu asumsi yang tidak pernah dinyatakan pada buku-buku teks standar Manajemen Keuangan dan Analisis Laporan Keuangan, bahwa yang dibahas adalah laporan keuangan perusahaan, yang dihitung adalah kinerja keuangan perusahaan. Sedangkan yang dimaksud dengan perusahaan adalah Perseroan Terbatas atau Limited Liability Corporation, yang sudah ada pemisahan antara kepemilikan perusahaan dengan kepengurusan perusahaan, yang merupakan sumber agency problems.

Mengikuti Klein (2012), penelitian ini berargumen dengan memenuhi tiga prinsip dasar theorizing, yakni: (1) teori apa? (2) mengapa? dan (3) kemaslahatan yang didapat. Dua perusahaan multinasional yang beroperasi dengan badan hukum Indonesia dan saham-sahamnya tercatat di Bursa Efek Indonesia, yakni PT Good Year 
Indonesia, Tbk dan PT Unilever Indonesia, Tbk ternyata selama lima tahun terakhir memiliki kondisi current ratio di bawah satu, yang oleh karenanya juga menikmati negative net working capital, namun saham-sahamnya merupakan saham darling para investor dan malahan salah satunya selalu bertahan menjadi saham penyusun Indeks LQ-45 selama beberapa tahun terakhir (Haikal 2014).

Tabel I

PT Unilever Indonesia, Tbk

\begin{tabular}{|c|c|c|c|c|c|}
\hline URAIAN & 2014 & 2013 & 2012 & 2011 & 2010 \\
\hline \multicolumn{6}{|l|}{ UNTUK TAHUN BERJALAN } \\
\hline Penjualan bersih & 34,511 & 30,757 & 27,303 & 23,469 & 19,690 \\
\hline Harga pokok penjualan & $(17,412)$ & $(14,979)$ & $(13,414)$ & $(11,463)$ & $(9,485)$ \\
\hline Laba bruto & 17,099 & 15,778 & 13,889 & 12,006 & 10,205 \\
\hline Beban usaha & $(9,337)$ & $(8,614)$ & $(7,391)$ & $(6,438)$ & $(5,662)$ \\
\hline Laba usaha & 7,762 & 7,164 & 6,498 & 5,568 & 4,543 \\
\hline Laba sebelum pajak penghasilan & 7,677 & 7,159 & 6,467 & 5,575 & 4,546 \\
\hline $\begin{array}{l}\text { Jumlah pendapatan komprehensif tahun } \\
\text { berjalan }\end{array}$ & 5,739 & 5,353 & 4,839 & 4,163 & 3,387 \\
\hline EBITDA & 8,136 & 7,675 & 6,857 & 5,929 & 4,832 \\
\hline \multicolumn{6}{|l|}{ PADA AKHIR TAHUN } \\
\hline Aset lancar* & 6,337 & 5,218 & 4,390 & 3,792 & 3,397 \\
\hline Jumlah aset & 14,281 & 12,703 & 11,339 & 9,828 & 8,350 \\
\hline Liabilitas jangka pendek* & 8,865 & 7,775 & 6,890 & 5,820 & 4,052 \\
\hline Jumlah liabilitas & 9,682 & 8,449 & 7,371 & 6,147 & 4,301 \\
\hline Ekuitas & 4,599 & 4,255 & 3,968 & 3,681 & 4,049 \\
\hline Model kerja bersih & $(2,528)$ & $(2,557)$ & $(2,500)$ & $(2,028)$ & $(655)$ \\
\hline Marjin laba bruto & $49,5 \%$ & $51,3 \%$ & $50,9 \%$ & $51,2 \%$ & $51,8 \%$ \\
\hline Marjin laba usaha & $22,5 \%$ & $23,3 \%$ & $23,7 \%$ & $23,7 \%$ & $23,1 \%$ \\
\hline $\begin{array}{l}\text { Marjin jumlah pendapatan komprehensif } \\
\text { tahun berjalan }\end{array}$ & $16,6 \%$ & $17,4 \%$ & $17,7 \%$ & $17,7 \%$ & $17,2 \%$ \\
\hline Jumlah saham beredar (dalam jutaan saham) & 7,630 & 7,630 & 7,630 & 7,630 & 7,630 \\
\hline $\begin{array}{l}\text { Laba bersih per saham dasar (dalam nilai } \\
\text { penuh Rupiah) }\end{array}$ & 752 & 701 & 634 & 546 & 444 \\
\hline $\begin{array}{l}\text { Pembayaran dividen per saham (dalam nilai } \\
\text { penuh Rupiah) }\end{array}$ & 707 & 664 & 594 & 594 & 399 \\
\hline Jumlah Pembayaran Dividen & 5,394 & 5,066 & 4,547 & 4,532 & 3,044 \\
\hline \multicolumn{6}{|l|}{ RASIO USAHA } \\
\hline Laba usaha terhadap ekuitas & $168,8 \%$ & $168,4 \%$ & $163,8 \%$ & $151,3 \%$ & $112,2 \%$ \\
\hline $\begin{array}{l}\text { Jumlah pendapatan komprehensif tahun } \\
\text { berjalan terhadap ekuitas }\end{array}$ & $124,8 \%$ & $125,8 \%$ & $121,9 \%$ & $113,1 \%$ & $83,6 \%$ \\
\hline Laba usaha terhadap jumlah aset & $54,4 \%$ & $56,4 \%$ & $57,3 \%$ & $56,7 \%$ & $54,4 \%$ \\
\hline $\begin{array}{l}\text { Jumlah pendapatan komprehensif tahun } \\
\text { berjalan terhadap jumlah aset }\end{array}$ & $40,2 \%$ & $42,1 \%$ & $42,7 \%$ & $42,4 \%$ & $40,6 \%$ \\
\hline \multicolumn{6}{|l|}{ RASIO KEUANGAN } \\
\hline Aset lancar terhadap liabilitas jangka pendek & $71,5 \%$ & $67,1 \%$ & $63,7 \%$ & $65,2 \%$ & $83,8 \%$ \\
\hline Jumlah liabilitas terhadap ekuitas & $210,5 \%$ & $198,6 \%$ & $185,8 \%$ & $167,0 \%$ & $106,2 \%$ \\
\hline Jumlah liabilitas terhadap jumlah aset & $67,8 \%$ & $66,5 \%$ & $65,0 \%$ & $62,5 \%$ & $51,5 \%$ \\
\hline
\end{tabular}

Sumber: Laporan Tahunan PT Unilever Indonesia, Tbk Tahun 2014 


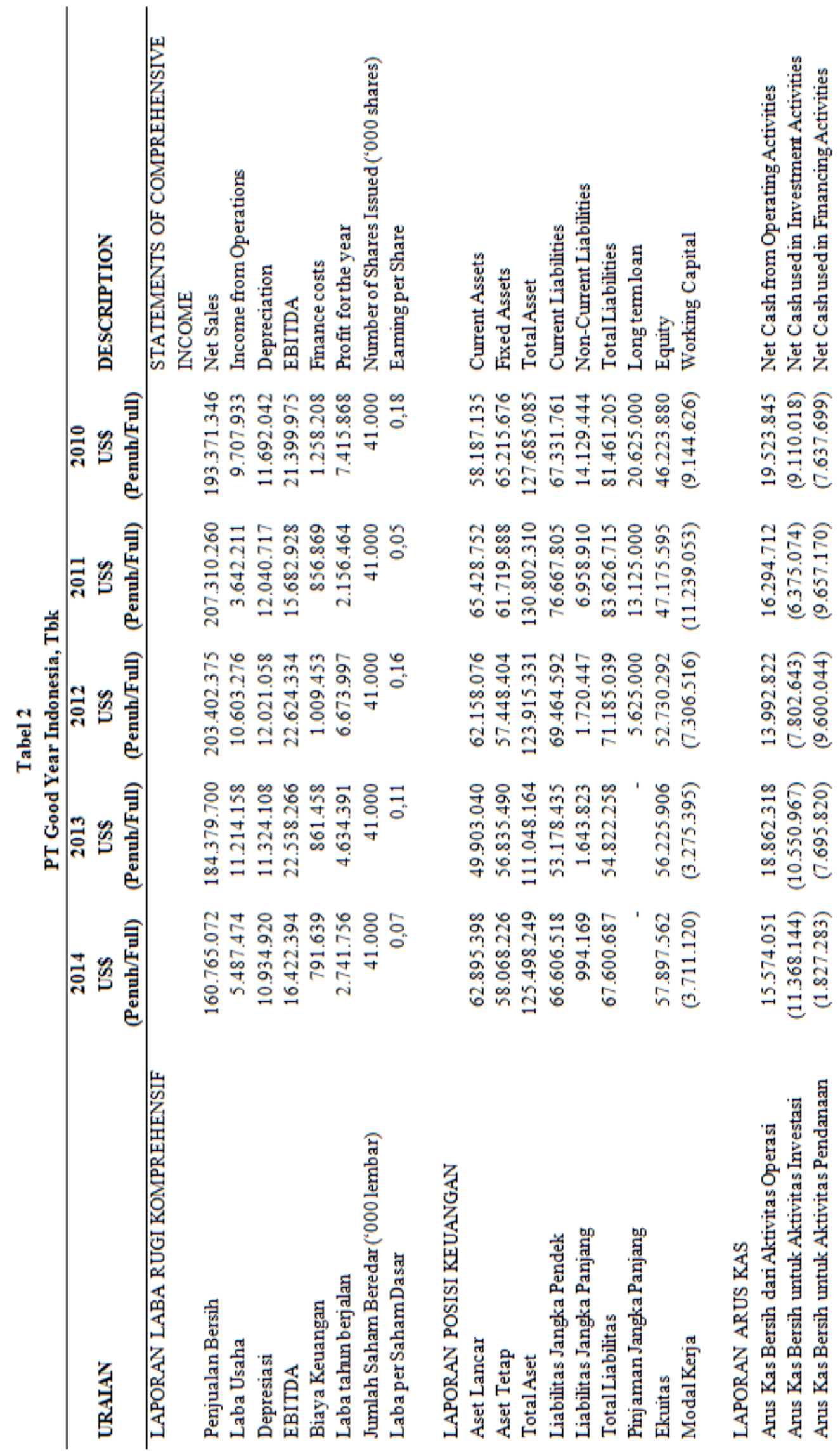




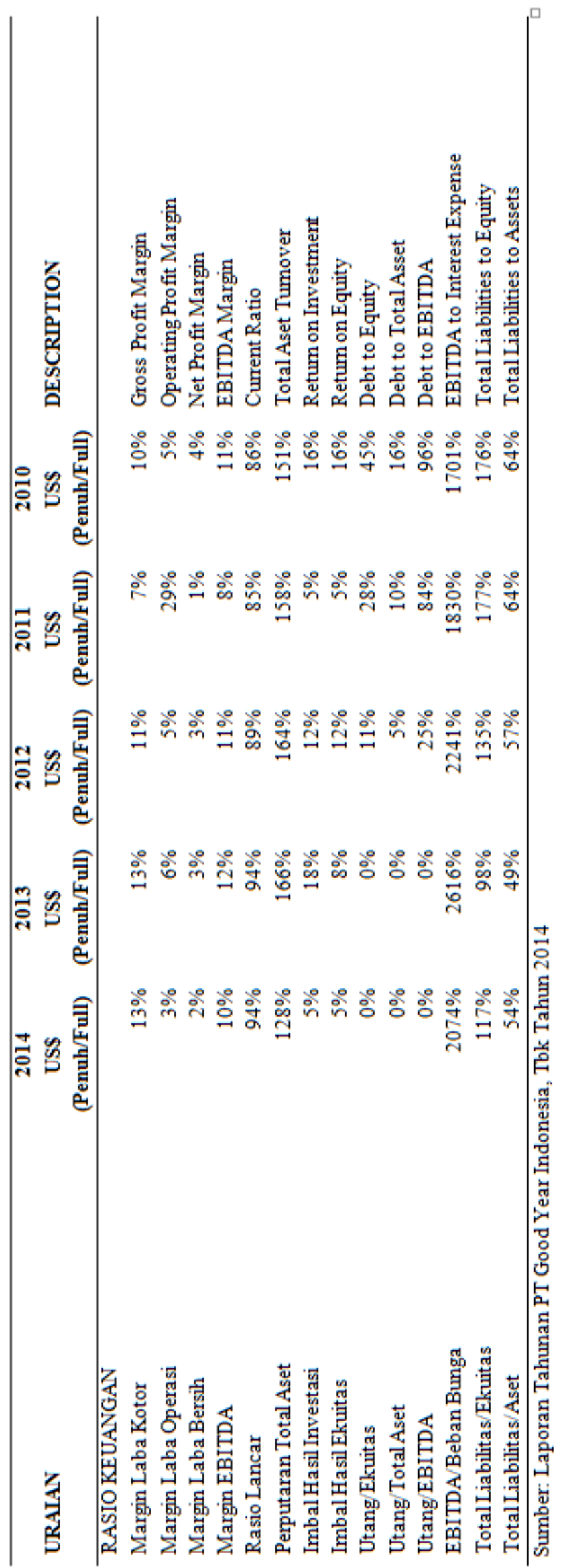


Tabel 3

PT Jasa Marga (Persero), Tbk

\begin{tabular}{|c|c|c|c|c|c|}
\hline \multicolumn{2}{|l|}{ Ikhtisar Keuangan 2010-2014 } & \multicolumn{4}{|c|}{ (dalam Rp miliar, kecuali dinyatakan lain } \\
\hline $\begin{array}{l}\text { LABA RUGI KOMPREHENSIF } \\
\text { KONSOLIDASIAN }\end{array}$ & 2010 & 2011 & 2012 & 2013 & 2014 \\
\hline Pendapatan Usaha & 4.379 & 6.486 & 9.070 & 10.271 & 9.175 \\
\hline Beban Usaha & $(2.390)$ & $(4.155)$ & $(6.095)$ & $(8.012)$ & $(6.131)$ \\
\hline Laba Usaha & 1.988 & 2.330 & 2.975 & 2.259 & 3.044 \\
\hline Laba Sebelum Pajak & 1.476 & 1.590 & 2.055 & 1.311 & 1.822 \\
\hline Beban Pajak & $(292)$ & $(411)$ & $(519)$ & $(382)$ & $(607)$ \\
\hline \multicolumn{6}{|l|}{ Laba Periode Berjalan yang Dapat } \\
\hline \multicolumn{6}{|l|}{ Diatibusikan kepada: } \\
\hline Pemilik Entitas Induk & 1.193 & 1.196 & 1.602 & 1.028 & 1.403 \\
\hline Kepentingan Non Pengendali & (9) & $(17)$ & $(66)$ & $(99)$ & $(188)$ \\
\hline Total Laba (Rugi) Periode Berjalan & 1.184 & 1.179 & 1.536 & 929 & 1.215 \\
\hline \multicolumn{6}{|l|}{ Laba Komprehensif yang Dapat } \\
\hline \multicolumn{6}{|l|}{ Diatribusikan kepada: } \\
\hline Pemilik Entitas Induk & 1.195 & 1.198 & 1.603 & 1.026 & 1.404 \\
\hline Kepentingan Non Pengendali & (9) & $(17)$ & $(66)$ & (99) & $(188)$ \\
\hline Total Laba (Rugi) Komprehensif & 1.186 & 1.180 & 1536 & 928 & 1.216 \\
\hline \multicolumn{6}{|l|}{ DATA SAHAM } \\
\hline Jumlah Saham yang Beredar (juta lembar) & 6.775 & 6.775 & 6.800 & 6.800 & 6.800 \\
\hline Laba Bersih per Saham (Rupiah penuh) & 176 & 177 & 236 & 151 & 206 \\
\hline Dividen per Saham (Rupiah penuh) & 106 & 79 & 94 & 79 & ** \\
\hline \multicolumn{6}{|l|}{ LAPORAN POSISI KEUANGAN } \\
\hline \multicolumn{6}{|l|}{ KONSOLIDASIAN } \\
\hline Total Aset & 18.952 & 20.916 & 24.754 & 28.059 & 31.858 \\
\hline Total Liabilitas & 10.593 & 12.555 & 14.966 & 17.501 & 20.433 \\
\hline Total Ekuitas & 8.359 & 8.361 & 9.788 & 10.558 & 11.425 \\
\hline Belanja Modal & 1.181 & 2.304 & 1.832 & $4.931 * * *$ & $4.788 * * *$ \\
\hline Investasi pada Perusahaan Asosiasi & 201 & 201 & 176 & 179 & 171 \\
\hline Modal Kerja Bersih & 1.612 & 228 & $(2.117)$ & $(1.083)$ & $(672)$ \\
\hline \multicolumn{6}{|l|}{ RASIO KEUANGAN (\%) } \\
\hline Rasio Laba (Rugi) terhadap Aset & 6,30 & 5,72 & 6,47 & 3,66 & 4,41 \\
\hline Rasio Laba (Rugi) terhadap Ekuitas & 14,28 & 14,31 & 16,37 & 9,73 & 12,28 \\
\hline Rasio Laba (Rugi) terhadap Pendapatan & 273,26 & 18,45 & 17,66 & 10,01 & 15,30 \\
\hline Rasio Lancar & 165,04 & 98,21 & 68,16 & 77,77 & 84,43 \\
\hline Rasio Liabilitas terhadap Ekuitas & 126,71 & 150,00 & 152,90 & 165,76 & 178,84 \\
\hline $\begin{array}{l}\text { Rasio Liabilitas terhadap Jumlah Aset } \\
\text { RASIO INDUSTRI }\end{array}$ & 55,89 & 60,03 & 60,46 & 62,37 & 64,14 \\
\hline $\begin{array}{l}\text { Rasio Pendapatan Tol terhadap Panjang } \\
\text { Jalan (Rp miliar/km) }\end{array}$ & 8,11 & 8,89 & 10,24 & 10,36 & 11,53 \\
\hline $\begin{array}{l}\text { Rasio Pendapatan Tol terhadap Jumlah } \\
\text { Karyawan (Rp miliar/km) }\end{array}$ & 0,81 & 0,94 & 1,10 & 1,19 & 1,42 \\
\hline $\begin{array}{l}\text { *) Disajikan kembali } \\
\text { **) Akan ditentukan dalam RUPS tahun } \\
\text { ***) Total Belanja Modal Konsolidasi }\end{array}$ & & & & & \\
\hline
\end{tabular}

Sumber: Laporan Tahunan PT Jasa Marga (Persero), Tbk Tahun 2014

Berdasarkan rumusan current ratio di bawah satu dan negative net working capital, kedua perusahaan mengalami unhealthy financial condition. Tetapi ternyata kenyataannya sangat jauh berbeda. Makalah ini akan membuktikan bahwa per se tata kelola perusahaan, current ratio rule of thumbs harus lebih besar dari satu dan net working capital harus positip, sudah usang dan obsolet. 
Hasil penelitian ini akan bermanfaat bagi pendidik, agar pendidik tidak begitu saja menerima ("as it is") pengertian current ratio dan turunannya dan meneruskan begitu saja kepada peserta didik serta kemudian lebih memperjelas pengertian net working capital dan memperluas penjelasannya kepada pengertian gross working capital. Bagi peneliti, agar tidak menganggap tabu theorizing. Para peneliti perlu paham dan menghayati bahwa penelitian-penelitian yang perlu dilakukan tidak saja dalam konteks justifikasi (context of justification) tetapi justru harus dimulai juga dari konteks discovery.

\section{ANALISIS DAN PEMBAHASAN}

Current ratio dan kemudian net working capital adalah hasil dari dua operasi aljabar yakni pembagian dan pengurangan antara current assets dan current liabilities. Berbagai buku tekspun menggunakan secara interchangeably atas istilah net working capital dengan working capital dan tidak secara eksplisit menyebutkan gross working capital. Working capital adalah gross capital yang terdiri dari seluruh komponen pada current asset, yakni capital (bukan ekuitas) yang digunakan perusahaan untuk memproduksi barang dan jasa. Semakin kecil "capital" yang diperlukan untuk memproduksi barang dan jasa, tentu saja semakin efisien. Hal ini dapat dianalogikan dengan perhitungan $R O E$ yang merupakan pembagian laba bersih dengan ekuitas. Dengan laba yang sama besar, tetapi ekuitasnya dikecilkan, maka $R O E$ semakin besar. Perusahaan semakin efisien dalam penggunaan modal ekuitasnya. $R O E$ yang besar adalah kondisi yang tentu saja favorable bagi pemegang saham. ROE yang besar merupakan kondisi yang dapat terjadi karena tiga alternatif: (1) laba bersih meningkat sedangkan ekuitas tetap (2) laba bersih tetap sama (tidak berubah) tetapi ekuitas lebih kecil (3) kombinasi (1) dan (2). Ekuitas adalah bentuk komitmen pemegang saham untuk perusahaan dalam bentuk setoran modal (modal disetor) dan komitmen pemegang saham terhadap perusahaan untuk tidak membagikan dividen dan memilih menabungnya di perusahaan dalam bentuk laba di tahan (retained earnings). Tidak cukup jelas mengapa kemudian terms net working capital yang diukur dari pengurangan current asset dari current liabilities digunakan untuk mengukur likuiditas perusahaan. Pemberian istilah yang absurd, karena pada saat menjelaskan Laporan Posisi Keuangan (balance sheets), sisi liabilitas dan ekuitas disebut sebagai sources of funds sedangkan sisi aset disebut sebagai uses of funds.

Jika konsisten dengan konsep sources and uses of funds, tidak pada tempatnya term net working capital yang merupakan operasi aljabar current assets dikurangi dengan current liabilities. Sebaliknya jika konsisten dengan konsep sources and uses of funds, maka seharusnya malahan current liabilities harus lebih besar dari current assets.

Hal ini dapat dimaklumi karena financial management atau corporate finance seolah-olah lahir begitu saja dan melupakan entrepreneurial finance. Bentuk badan hukum CV, NV, firma, persekutuan perdata hingga Perseroan Terbatas adalah 
berbagai tahapan metamorfosis badan hukum perusahaan yang bermula dari usaha perorangan (yang mengandalkan diri sendiri dan sanak famili yang tidak memiliki perbedaan kepentingan) sampai terjadinya pemisahan kepemilikan dengan pengelolaan (separation of ownerships and control) dalam bentuk Perseroan Terbatas, yang sarat dengan agency problem. Pemilik perusahaan hanya mendapat ampas dan karenanya disebut residual claimant sedangkan saripatinya dinikmati oleh orang lain. Pemilik perusahaan (pemegang saham) hanya dapat meminta pertanggungjawaban pengelolaan perusahaan melalui RUPS yang dilakukan setahun sekali. Itulah sebabnya mengapa pemegang saham perlu menempatkan Dewan Komisaris yang bertugas melaksanakan fungsi oversight, menugaskan Kantor Akuntan Publik untuk memeriksa laporan keuangan.

Dimulai dari usaha kecil milik perorangan, pada khazanah entrepreneurial finance, ditemukan istilah financial bootstrapping (Winborg \& Landström 2001). Secara umum bootstrapping dimaknai sebagai sebagai proses yang berjalan terus menerus, berkelanjutan yang diupayakan tanpa memerlukan input eksternal. Bootstrapping adalah kombinasi berbagai upaya untuk mengurangi kebutuhan modal, meningkatkan arus kas. Dari hasil pengamatannya keduanya menemukan duapuluh sembilan teknik bootstrapping yang dapat dikelompokkan dalam enam metoda: owner-provided resources and financing; account receivables management; sharing or borrowing of resources from other firms; delaying payments; minimization of resources invested in stock through formal routines; use of government subsidies. Berbagai metoda bootstrapping tersebut tidak digunakan bersama-sama tetapi bersifat kondisional pada kondisi unik yang dihadapi oleh entrepreneur (Ebben 2009).

Pada kondisi owner-manager yang bertolak belakang dengan separation of ownerships and control, tidak terdapat agency problem karena principal mengerjakan langsung segala sesuatunya, ternyata upaya meminimalisir (yang kemudian disebut sebagai current ratio) current asset dan memperbesar current liabilities merupakan bagian penting dari entrepreneurial finance dan disebut sebagai financial bootstrapping.

Menunda membayar utang dagang (account payable) tidak berarti wanprestasi selama pembayaran masih dilakukan dalam kerangka waktunya. Tidak dipenuhinya term utang dagang " $2 / 10, \mathrm{n} / 30$ " tidak berarti wanprestasi, tetapi merupakan pilihan untuk memanfaatkan atau tidak memanfaatkan sales discount dari pemasok. Upah buruh adalah direct cost yang secara teknis dimungkinkan dibayar setiap kali buruh masuk dan bekerja. Namun pembayaran upah buruh langsung dibayar secara mingguan atau bahkan bulanan, juga merupakan teknik menunda pembayaran. Beberapa ritel besar baru membayar pemasoknya setelah satu atau dua bulan juga merupakan teknik menunda pembayaran.

Sebaliknya dengan berevolusinya teknik keuangan, piutang yang baru akan terkumpul satu bulan ke depan, dapat dijual kepada perusahaan anjak piutang 
(factoring) yang bersedia membeli piutang dan juga menanggung risiko tidak tertagihnya piutang. Penjualan piutang (factors) berbeda dengan utang bank yang menggunakan piutang sebagai jaminan. Utang bank juga akan membebani perusahaan dengan peningkatan rasio leverage.

Di bidang manajemen produksi dan distribusi, berbagai teknik diciptakan untuk meminimalisir persediaan, baik persediaan bahan baku, barang setengah jadi atau barang jadi. Berbagai istilah Just In Time Inventory Model, Lean Production Model dan kemudian dirangkum dalam bentuk Supply Chain Management. Kesemuanya ditujukan untuk memperpendek waktu proses dari bahan baku dari supplier menjadi barang jadi kepada konsumen.

Satu-satunya argumen yang selalu dan seringkali digunakan untuk membela current ratio harus lebih besar dari satu adalah term permanent current asset. Permanent current asset akan eksis jika terdapat lead time atau lag time dalam pengelolaan persediaan. Lead time akan terjadi pada kondisi manajemen logistik dan transportasi yang buruk. Indonesia sebagai negara kepulauan memang merupakan negara dengan tranportasi yang buruk, namun kembali ke contoh perusahaan, yakni UNVR yang mengoperasikan empat pabrik, tiga di antaranya di Cikarang dan satu di Surabaya atau GDYR dengan hanya satu pabrik di Bogor tetapi area distribusinya meliputi seluruh Indonesia ternyata mampu menjaga dan mempertahankan current ratio dibawah satu dan karenanya (sehingga) tidak membebani pemegang saham dengan penggunaan long-term and interest bearing liabilities untuk "membiayai" permanent current assets.

Pada industri jasa yang tidak memiliki current asset yang dapat dilabeli dengan permanent current assets sebagai pembenaran current ratio diatas satu, yang komponen inventorynya minimal atau tidak signifikan, seharusnya bercurrent ratio juga dibawah satu. Jasa Marga selama empat tahun berturut-turut menikmati current ratio dibawah satu sebagaimana Tabel 3. Perusahaan-perusahan sejenis dengan Jasa Marga, yakni service operation, penjualan seratus persen dilakukan secara kas, seharusnya memiliki profil current ratio sama dengan Jasa Marga.

\section{SIMPULAN, KETERBATASAN DAN SARAN}

\section{Simpulan}

Hubungan current assets dengan current liabilities dengan dua operasi aljabar, melalui pembagian disebut current ratio harus lebih besar dari satu dan melalui pengurangan disebut net working capital harus berselisih positif, merupakan bentuk misapropriasi pemegang saham. Pada badan usaha tanpa agency problem, justru dianjurkan menggunakan metoda financial bootstrapping untuk meminimalisir current ratio. Terminologi net working capital tidak konsisten dengan term sources and uses of funds of balance sheet. 


\section{Implikasi}

Penelitian-penelitian yang menggunakan current ratio dan net working capital serta working capital sebagai variabel untuk mengukur kesehatan perusahaan dan rating yang diberikan oleh perusahaan pemeringkat yang didalam metodologi pemeringkatannya memasukkan ketiga unsur tersebut hanya sahih bagi kepentingan kreditur, bukan bagi kepentingan pemegang saham.

\section{Saran}

Manuskrip ini bukanlah hasil penelitian, melainkan upaya theorizing. Sangat boleh jadi, bukan suatu kebetulan, jika dua perusahaan yang bertahun-tahun menikmati current ratio dan negative net working capital bergerak di industri fast moving goods dan bagian dari kelompok usaha perusahaan multinasional. Perusahaan yang lainnya yang menjadi contoh adalah Jasa Marga, perusahaan jasa operator jalan bebas hambatan yang seluruh pendapatannya bersifat tunai dan tidak memerlukan persediaan. Oleh karenanya, terbuka peluang yang luas untuk melakukan survey menyeluruh terhadap seluruh perusahaan dari berbagai macam industri di luar industri jasa keuangan yang tercatat di Bursa Efek Indonesia baik yang merupakan entitas tunggal maupun bagian dari kelompok usaha. Survey terlebih dahulu sebelum melakukan riset adalah urutan proses yang perlu dilakukan agar tidak dikategori sebagai armchair economist (Simon 1986).

\section{DAFTAR PUSTAKA}

Berle, A. A. 1931. "Corporate powers as powers in trust." Corporate Governance: Values, Ethics and Leadership 44 (7): 1049-74. https://doi.org/10.4324/9781315574288.

Dodd, E. Merrick. 1932. "For whom are corporate managers trustees?" Corporate Governance: Values, Ethics and Leadership 45 (7): 1145-63. https://doi.org/10.4324/9781315574288.

Durkheim, Emile. 1982. The rules of sociological method. Diedit oleh Steven Lukes. United States of America.

Ebben, Jay J. 2009. "Bootstrapping and the financial condition of small firms." International Journal of Entrepreneurial Behaviour and Research 15 (4): 34663. https://doi.org/10.1108/13552550910967930.

Haikal, S. 2014. “Memaknai Current Ratio.” Kontan Mingguan, 2014.

Janssen, M. 2002. "The einstein-besso manuscript: A glimpse behind the curtain of the wizard."

Jensen, Michael C., dan William H. Meckling. 1976. "Theory of the firm: Managerial behavior, agency costs and ownership structure." Journal of Financial Economics 3 (4): 305-60. https://doi.org/10.1016/0304-405X(76)90026-X.

Klein, D.B. 2012. “Disciplining Your Theorizing: Three Frank Questions.” Working 
Paper in Ecnomics.

Klein, Daniel B, dan Pedro P Romero. 2007. "Model Building versus theorizing: The paucity of theory in the journal of economic theory." Economic Journal Watch 4 (2): 241-71.

Lummus, Rhonda R., dan Robert J. Vokurka. 1999. "Defining supply chain management: a historical perspective and practical guidelines." Industrial Management \& Data Systems $99 \quad$ (1): $11-17$. https://doi.org/10.1108/02635579910243851.

Miller, Merton H. 1999. "The history of finance: An eye witness account.” The Journal of Portfolio Management 13 (2): 95-101.

Roos, S.A, R.W Westerfield, dan B.D Jordan. 2013. Fundamentals of corporate finance 10th edition. McGraw Hill.

Saito, A.T, J. Savoia, dan R. Fama. 2013. "Financial theory evolution.” International Journal of Education and Research 1 (4): 1-18.

Simon, Herbert A. 1986. “The failure of armchair economics.” Challenge, 1986.

Subramanyam, K.R, dan J.J Wild. 2009. Financial statement analysis 10th edition. McGraw Hill International Student.

Swedberg, Richard. 2012. "Theorizing in sociology and social science: Turning to the context of discovery." Theory and Society 41 (1): 1-40. https://doi.org/10.1007/s11186-011-9161-5.

Volk, Greg. 2009. “39 Questionable assumptions in modern physics, space, propulsion \& energy sciences international forum.” In AIP Conference Proceedings, 116.

Winborg, Joakim, dan Hans Landström. 2001. "Financial bootstrapping in small businesses: Examining small business managers' resource acquisition behaviors." Journal of Business Venturing $16 \quad$ (3): 235-54. https://doi.org/10.1016/S0883-9026(99)00055-5. 
